\title{
Does Electricity Access Relate to Stakeholders' Satisfaction? Empirical Evidence from Small and Medium Enterprises in North-West, Nigeria
}

\section{Abubakar Sabo ${ }^{1 \rtimes}$ Olusegun Kazeem Lekan²}

Department of Business Administration, Faculty of Management Sciences, Usmanu Danfodiyo University, Sokoto, Nigeria.

${ }^{2}$ Department of Business Management, Faculty of Management Sciences, Federal University Dutsinma, Katsina, Katsina State, Nigeria.

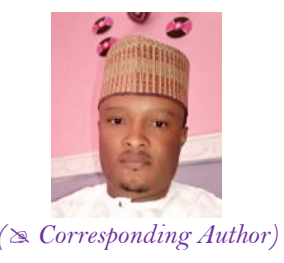

T) Check for updates

\section{Abstract}

Several scholarly studies have been conducted to establish relationships of electricity access to business financial performance. Nonetheless, little is known about energy-stakeholders' satisfaction relationships. The few studies that do exist on the topic often lack control variable. Thus, this is the motivation behind the present study. Therefore, this paper provides an empirical analysis of the effect of controlling firm characteristics in the energy-stakeholders' satisfaction relationships. A multiple linear regression model is applied to primary data collected through structured questionnaire in five-point rating scale format to test the hypothesis via SPSS version 23. Results based on cross-sectional survey data from 245 sampled SMEs operating in the city of Kaduna, Kano, Katsina and Sokoto state in manufacturing, hotel \& restaurant and wholesale \& retail sector show evidence of a strong positive statistically significant relationships between electricity access and SMEs stakeholders' satisfaction with electricity access $t(245)=9.138, \mathrm{p}<$ 0.001 ; firm age $\mathrm{t}(245)=4.404, \mathrm{p}<0.001$. Subject to appreciable effect on stakeholders' satisfaction, this study recommends an urgent need to step up electricity supply to SMEs in order to accelerate satisfaction level of firms' stakeholders. Increasing electricity access should involve optimal production and utilization of generation capacity and/or reduction of transmission and distribution losses. Above all, SMEs villages/clusters should be built to promote industrial activities on the basis that access to reliable electricity supply is collectively and affordably provided by the relevant host authorities to investors and operators.

Keywords: Electricity access, Stakeholders' satisfaction, Firm age, Firm size, Leverage, SMEs.

JEL Classification: L25.

\section{Contribution of this paper to the literature}

This paper provides an empirical analysis of the effect of controlling firm characteristics in the energy-stakeholders' satisfaction relationships.

\section{Introduction}

Access to a reliable electricity supply is widely considered to be vital and indispensable to the operations of most small and medium enterprises (SMEs). A scholar (Krizanic, 2007) likened indispensability of reliable electric power to the role of food in the body. Just as food is needed to survive and grow, reliable electricity is also a necessary condition for businesses to thrive. Electricity consumption will increase productivity and therefore growth is achieved. Not surprising, most economists today agree that modern energy is a necessary ingredient for stimulating the emergence, growth and continued development of small scale businesses subsector in all societies.

However, surveys suggest that, in middle and lower income countries, firms themselves consider access to electricity to be one of the biggest constraints to their business. In the World Economic Forum Global Competitiveness Report 2013 - 2014, quality of Nigeria's electricity supply ranks 141 out of 148 countries. Furthermore, $60 \%$ of Nigerian SMEs reported losing more than $10 \%$ of their sales to power outages. Electricity goes on and off five times in an hour (Okafor, 2014). This creates serious problems for firms. Equipment is damaged by power surges that usually accompany epileptic power and goods at various stages of manufacturing are damaged. Limited access to quality and quantity of electricity has remained an unresolved scourge in Nigeria.

Empirical evidence which can be used to validate the relationship between electricity and enterprises stakeholders' satisfaction is surprisingly scarce. The few studies that do exist on the topic often lack control variable. The research implication is that holistic relationships between the dependent and independent variables may be blurred and drawing clear-cut conclusion might be complicated. This was the motivation behind the present study. Hence, the current study seek to contribute to the existing literature by providing an extensive analytical framework that explore the role of control variable that is firm characteristics (firm size, firm age and leverage) in the relationships between electricity access and firms stakeholders' satisfaction in order to establish a 
true link between the studies variables and keep the results reasonable with stronger conclusion. The findings of this research are hoped to add to the existing body of literature, provide a better understanding of the subject matter to entrepreneurs, energy suppliers, policy makers and other modern energy stakeholders, and serve as a frame of future reference to researchers, academics and students.

\section{Literature Review}

\subsection{Review of Empirical Literature}

To date existing empirical evidence on the relationship between electricity and stakeholders' satisfaction of Nigerian SMEs is too sparse for satisfactorily conclusion. Substantial studies on this subject matter only give considerable attentions to financial performance of enterprises (profitability, liquidity, growth). For instance, using 1970-2000 panel data for South Africa, and a range of 19 infrastructure measures, Fadderke and Bogetic (2006) found that electricity generation is positively related to labour productivity and total factor productivity growth in South Africa. Furthermore, Kirubi et al. (2009)analysed community-based micro-girds in rural Kenya, and showed that use of electricity can increase productivity per worker by approximately $100-200 \%$ for carpenters and by $50-$ $170 \%$ for tailors, depending on the item being produced. In another study, Grimm et al. (2011) found that tailors in Burkina Faso with access to electricity have revenues $51 \%$ higher than tailors without electricity, and attribute this to the use of electric sewing machines and longer working hours. Although the evidence shows a correlation between electricity consumption and firm productivity, and firms with access to electricity tend to have higher productivity than firms without, establishing causality is complex. This is partly due to the range of exogenous factors, and partly to the nature of the impact of electricity itself.

Ukpong (1993) applied production function approach to investigate the impact of erratic power supply on selected firms in commercial and industrial sectors in Nigeria from 1965-1966. His finding shows that about 130 $\mathrm{KW} / \mathrm{H}$ and $172 \mathrm{KW} / \mathrm{H}$ were not supplied to the firms in the two periods. The estimated cost of this is N1.68 million in 1965 and N2.75 in 1966. By implication, he noted that erratic power supply has adverse impact on productivity growth of manufacturing sector in Nigeria. In the same vein, Akuru and Okoro (2011) assessed effect of electricity power outages on the growth and survival of firms in Nigeria, established that, between 2000 and 2008 around 820 manufacturing firms were closed down, with the figure moving up to 834 in the following year, all because of poor electricity power supply and high cost on the alternative energy supply.

Aligned with the foregoing, Doe and Asamoah (2014) examined effect of electric power fluctuations on the profitability and competitiveness of SMEs within Accra business district of Ghana is cross-sectional survey involved a mixed method approach. A sample of 70 Ghanaian SMEs was selected using a systematic sampling approach. Data was collected with an interviewer-administered structured questionnaire which focused on the effect of power fluctuation on the operations of SMEs, especially on the profitability and its resulting effect on the firms' competitiveness. The SPSS statistical package was used to group and analyse the data. The study is a singlefactor analysis of the exogenous problems facing the Small and Medium Enterprise sector. The study found that without reliable energy supply, SMEs are unable to produce in increased quantities and quality leading to poor sales hence low levels of profitability. It is established that low profitability negatively affects Return on Assets (ROA) and Return on Investment (ROI) of SMEs. Consequently, if the level of profitability is high, it is expected that ROA and ROI will be high and vice versa. With high profits, SMEs are able to increase their competitiveness.

A seminal work by Solomon and Yao (2015) in a case study among the cold store operators in the Asafo Market area of the Kumasi Metro in Ghana on electricity power insecurity and SMEs growth. Both primary and secondary data are utilized while purposive and stratified sampling technique are used to select 240 samples. The research findings indicate that, power outage experience has a negative effect on SMEs growth and pushes the operation cost of businesses high due to the high cost of alternative energy supply and the damages of assets through the power fluctuations. The operational cost in effect also have a damming effect on the growth of the SMEs, since most of the revenue meant for reinvesting will rather goes to the servicing of electricity and alternative power bills.

To clinch the above finding, Wang (2002) confirmed negative correlation between frequent (announced) power fluctuations and unannounced power outages with ROA and ROI. The costs of alternate power sources such as power generators, as well as expenditure on overtime pay to staff and outsourcing service cannot be avoided when there is power outage and that tends to affect the firms ROA and ROI.

It is evident from the aforementioned studies that empirical evidence which explicitly look at the correlation between electricity and satisfaction of SMEs stakeholders is too scanty for reasonable conclusion. Consequently, further research would be necessary.

\subsection{Theoretical Framework}

There are four major theoretical approaches to study SMEs performance. The first approach comprises the Balanced Scorecard (BSC) theory. BSC is a good strategy-management tool; it reviews the entire organization from four balanced perspectives. However, BSC is not sufficient to help SMEs because it does not examine many competitive and external factors. Furthermore, previous research has shown that BSC does not fit the flexible environment of SMEs because of BSC's inherent mechanization and inflexibility (McAdam, 2000). The second approach involves Performance Prism. It is not a prescriptive measurement framework; instead, it is a tool (framework) that helps management teams to think about key questions and strategies to address them. Yet, performance prism does not fit into flexible environment and lack dynamic adaptability. Besides, it lacks both internal and external determinants measurement. The very same benefits that make the Performance Prism a strong, comprehensive model, however, also make it difficult to easily utilize. The third approach comprises the Activity-Based Costing (ABC) which measures the cost of a resource used to perform organizational activities and then links the activity to the costs of the outputs. ABC is a significant SMEs theory as it includes key performance indicators and based on objective-oriented measures. However, it is difficult to employ ABC to measure external factors because it lacks flexibility and dynamic adaptabilities. In addition, ABC approach does not reflect competitive performance nor respond tostrategy development. Finally, the forth approach is the System Theory 
which regards an organization as a holistic system. Each part of the organization contributes to the system and ensures its survival and continuity. To achieve this objective, managers should not only understand the various parts of their organization and interconnection, but also the relationship of the system to its external environment (Jackson, 2003). System Theory can help SMEs to set-up a dynamic and flexible PM system which can measure both internal and external information, including competitive performance and respond quickly to strategy development. Subject to the SMEs performance requirements, system theory satisfies more SMEs performance (stakeholders' satisfaction) requirements than other theoretical approaches. Consequently, this theoretical approach is adopted in building a performance measurement framework for electricity-reliant SMEs.

\section{Research Methodology}

Correlational survey research design which is cross-sectional in nature was adopted for this study because data was collected at one time.There are three variables in this research. The independent variable is electricity access; dependent variable is SMEs stakeholders' satisfaction and control variable is firm characteristics. The unit of analysis is individual owner-manager. The target population consisted of SMEs operating in the city of Kaduna, Kano, Katsina and Sokoto state, Nigeria. Multi-stage sampling was applied to collected data from three stratums i.e manufacturing, hotel \& restaurant and wholesale \& retail sector SMEs. In the first stage, the SMEs were purposively selected; the next stage involved stratified sampling while SMEs were randomly selected in the third stage. A total of 340 sampled SMEs found with the aid of Krejcie and Morgan (1970) were invited to participate in the survey.

The available data to answer the research questions are readily quantitative and subjective in nature, and were obtained mainly through primary source. A structured questionnaire with closed ended questions is used to gather the study data with a five-point rating scale. Out of the 340 questionnaires distributed only two hundred and sixty two questionnaires were returned, which showed that seventy seven percent (77\%) of the respondents answered the questionnaires. Due to incomplete responses for some of the questions, nineteen (19) questionnaires were not analyzed. The final analysis was performed for only two hundred and forty five questionnaires (72\%). The questionnaire consists three parts and was designed to explore the relationships between the research variables. Part one comprises questions on SMEs stakeholders' satisfaction which was measured using a multi- item scale adopted from previous studies such as Hoskisson et al. (2008). Thirty items were used to measure SMEs stakeholders' satisfaction. Each item was measured using a five- point rating scale on which the owners had to rate the business satisfaction level over the last three years. 1 indicates short of below average and 5 indicating well above average. In part two, ten (10) items were developed to measure electricity access. Part three consists fourteen (14) items to measure firm characteristics.

The face and content validity of the questionnaire was ascertained by the assessment of specialists on the topic in order to determine the appropriateness of the items of the instrument, ascertain relevance and clear ambiguity. The coefficient of the Cronbach's Alpha was employed to determine internal reliability of the instrument which was o.82 thus, indicated that the items used for the measurement model are technically free from error. Descriptive statistics, mainly the frequency, percentage, mean and standard deviation, were used to analyze the data while multiple regression model was applied to test the hypotheses via SPSS version 23. All statistical tests were carried out at $95 \%$ significant level. The results of the hypothesis are presented in the next section.

\section{Data Analysis and Results}

\subsection{Descriptive Analysis of the Main Variables}

Table 1 depicts the mean, standard deviation and Pearson correlation between the study variables. The total sample selected from the population of this study consists of two hundred and forty five (245) SMEs. The dependent variables selected for this study is stakeholders' satisfactions. The independent variable is electricity access while control variables are firm size, firm age and leverage. Stakeholders' satisfactions had a mean of 83.42 with a standard deviation of 17.65. This signifies a fairly high increase in customers', employees' and owners' satisfaction. The results further indicate that during the period of study, accessibility per hour of electricity supply had a mean of 19.9 with a standard deviation of 6.47. Low variability of standard deviation implies that electricity supply average is a true representation of the sample mean. However, mean value of 19.9 reflects that the present capacity of electricity supply fall short of requirement. This creates serious problems for electricity-reliant firms. In terms of firm years of operation, the mean and standard deviation are 7.13 and 1.59 while the mean and standard deviation are 7.59 and 1.60 for firm size respectively. This signifies that the firms were dominated by young small scale businesses. It is also revealed that leverage has a mean of 9.10 with a standard deviation of 2.98 . This indicates a weak gearing position by the firms with a relatively low variability which could be attributed to the high cost of borrowing as a result of prevailing high interest rates in Nigeria.

Table 2 further provides a matrix of the correlation coefficients for the study variables. Each variable is perfectly correlated with itself and so $r=1$ along diagonal of the table. All the correlations were significant at 0.05 level. For instance, it is found that electricity access was positively related to stakeholder satisfaction at 0.05 significant levels with Pearson correlation coefficient of $r=0.646$. The result suggests that electricity supply is vital for SMEs stakeholders' satisfaction. This lends credence to the assertion that nearly all organizations need electricity services for proper functioning.

On the other hand, weak positive relationship exists between SMEs stakeholders' satisfaction and firm size. The relationship was significant at 0.05 levels. Pearson correlation coefficient was 0.386 with stakeholder satisfaction. The results give an indication that firm size is positively related to performance in terms of owners, customers and employees satisfaction.

Furthermore, firm age registered 0.493 correlations with stakeholder satisfaction. The result revealed that firm age has a significant weak positive correlation with SMEs stakeholder satisfaction. Finally, leverage showed a significantly weak positive relationship with SMEs performance. Leverage Pearson correlation coefficients was 0.166 with stakeholder satisfaction. The results suggest that firm leverage has comparatively lesser positive but significant correlation to SMEs stakeholder satisfaction. 
Table-1.Mean and standard deviation of study variables.

\begin{tabular}{c|c|c|c}
\hline Variables & Mean & Std. Deviation & $\mathbf{N}$ \\
\hline Elect access & 19.19 & 6.470 & 245 \\
\hline S. Satisfaction & 83.42 & 17.654 & 245 \\
\hline Age & 7.13 & 1.597 & 245 \\
\hline Size & 7.59 & 1.608 & 245 \\
\hline Leverage & 9.10 & 2.988 & 245 \\
\hline
\end{tabular}

Table-2.Pearson correlation coefficients of study variables.

\begin{tabular}{|c|c|c|c|c|c|c|}
\hline & & Elect access & Stakeholders satisfaction & Age & Size & Leverage \\
\hline \multirow[t]{3}{*}{ Elect access } & Pearson correlation & 1 & $.646^{* *}$ & $.456^{* *}$ & $.330^{* * *}$ & .059 \\
\hline & Sig. (2-tailed) & & .000 & .000 & .000 & .358 \\
\hline & $\mathrm{N}$ & 245 & 245 & 245 & 245 & 245 \\
\hline \multirow[t]{3}{*}{ S.Satisfaction } & Pearson correlation & $.646^{* *}$ & 1 & $.493^{* *}$ & $.386^{* * *}$ & $.166^{* * *}$ \\
\hline & Sig. (2-tailed) & .000 & & .000 & .000 & .009 \\
\hline & $\mathrm{N}$ & 245 & 245 & 245 & 245 & 245 \\
\hline \multirow[t]{3}{*}{ Age } & Pearson correlation & $.456^{* *}$ & $.493^{* * *}$ & 1 & $.264^{* *}$ & .032 \\
\hline & Sig. (2-tailed) & .000 & .000 & & .000 & .615 \\
\hline & $\mathrm{N}$ & 245 & 245 & 245 & 245 & 245 \\
\hline \multirow[t]{3}{*}{ Size } & Pearson correlation & $.330^{* *}$ & $.386^{* * *}$ & $.264^{* * *}$ & 1 & .014 \\
\hline & Sig. (2-tailed) & .000 & .000 & .000 & & .830 \\
\hline & $\mathrm{N}$ & 245 & 245 & 245 & 245 & 245 \\
\hline \multirow[t]{3}{*}{ Leverage } & Pearson correlation & .059 & $.166^{* * *}$ & .032 & .014 & 1 \\
\hline & Sig. (2-tailed) & .358 & .009 & .615 & .830 & \\
\hline & $\mathrm{N}$ & 245 & 245 & 245 & 245 & 245 \\
\hline
\end{tabular}

\subsection{Test of Hypotheses}

Since positive relationships were found between electricity access, SMES stakeholders' satisfaction and firm characteristics in the correlation analysis, it is deemed necessary to employ regression analysis in order to determine whether there are any predictive relationship between dependent and independent variables. Hence multiple regression analysis was performed to predict the research hypothesis. In this analysis, model was developed to establish whether electricity access is significantly related to SMEs stakeholder satisfaction. If the Pvalue is less than 0.05 the null hypothesis stands rejected. But the study accept null hypothesis if otherwise.

\subsubsection{Hypothesis}

HO: Electricity access is not significantly related to SMEs stakeholders' satisfaction.

Electricity was run against SMEs stakeholder satisfaction while firm characteristics were included as control variables on two hundred and forty five (245) observations. The result revealed that the model had an $\mathrm{R}$ square equal to 0.507 indicating that $50.7 \%$ of the variations in SMEs stakeholder satisfaction are explained by the four variables entered in the model (electricity access, firm size, firm age and leverage). As can be seen in Table 3 the difference between the value of $\mathrm{R}$ square and adjusted $\mathrm{R}$ square $(0.507-0.499=0.006)$ is very small. This shrinkage value means that if the model were derived from the population rather than a sample it would account for approximately $0.006 \%$ less variance in the outcome. Consequently adjusted $\mathrm{R}$ square indicates that the cross validity of this model is very good. This result was further buttressed with prediction of whether change in $\mathrm{R}$ square was significant at an F-ratio of 61.778 , which is again significant $(\mathrm{P}<0.001)$. The change statistics therefore revealed the difference made by adding firm characteristics to the model. Similarly, the F-statistics (ANOVA) of the model in Table 4 equal 61.778 , with a p-value equal to 0.000. The ANOVA finding showed that the overall model is a significant predictor of the SMEs stakeholders' satisfaction.

Table-3.Relationship between SMEs stakeholder satisfaction and predictors.

\begin{tabular}{c|c|c|c|c|c|c|c|c|c|c}
\hline \multirow{2}{*}{ Model } & \multirow{2}{*}{$\mathbf{R}$} & \multirow{2}{*}{$\begin{array}{c}\mathbf{R} \\
\text { square }\end{array}$} & \multirow{2}{*}{$\begin{array}{c}\text { Adjusted } \\
\text { R square }\end{array}$} & $\begin{array}{c}\text { Std. Error } \\
\text { of the } \\
\text { estimate }\end{array}$ & $\begin{array}{c}\text { R square } \\
\text { change }\end{array}$ & $\begin{array}{c}\text { F } \\
\text { change }\end{array}$ & df1 & df2 & Sig. F change & $\begin{array}{l}\text { Durbin- } \\
\text { Watson }\end{array}$ \\
\hline 1 & $.712^{\mathrm{a}}$ & .507 & .499 & 12.495 & .507 & 61.778 & 4 & 240 & .000 & 2.409 \\
\hline
\end{tabular}

a. Predictors: (Constant), Leverage, Size, Age, Elect Access.

b. Dependent Variable: Stakeholder Satisfaction.

Table-4.Variance analysis of SMEs stakeholder satisfaction and predictor.

\begin{tabular}{|c|c|c|c|c|c|c|}
\hline \multicolumn{2}{|c|}{ Model } & Sum of squares & Df & Mean square & $\mathbf{F}$ & Sig. \\
\hline \multirow[t]{3}{*}{$\overline{1}$} & Regression & 38578.016 & 4 & 9644.504 & 61.778 & $.000^{b}$ \\
\hline & Residual & 37467.682 & 240 & 156.115 & & \\
\hline & Total & 76045.698 & 244 & & & \\
\hline
\end{tabular}

a. Dependent Variable: Stakeholder Satisfaction.

b. Predictors: (Constant), Leverage, Size, Age, Elect Access.

The results further indicate in Table 5 individual contribution of each predictor to the t-test model. The slope that is b-values show the relationship between SMEs stakeholder satisfaction and each predictor. For these data all the four predictors have positive b-values signifying positive relationships. So, as electricity access increases by one unit, SMEs stakeholder satisfaction increase by 1.311 units provided the effect of firm characteristics that is firm age, firm size and leverage are held constant. Besides, every additional firm age increase is associated with an extra 2.501 of SMEs stakeholder satisfaction provided electricity access, firm size and leverage are held constant. Beta weight under unstandardized coefficient also indicated that a unit increase on both firm size and leverage can expect addition of SMEs stakeholder satisfaction of 1.826 and 0.754 respectively provided other predictors too are 
held fixed. For this model, electricity supply and firm age were significant predictors of SMEs stakeholder satisfaction. Electricity access $\mathrm{t}(245)=9.138, \mathrm{p}<0.001$; firm age $\mathrm{t}(245)=4.404, \mathrm{p}<0.001$; firm size $\mathrm{t}(245)=$ 3.434; and leverage $t(245)=2.813$.

From the magnitude of the t-statistics, electricity supply had the greatest predictive power followed by firm age whereas both firm size and leverage had similar less impact. However, in order to evaluate the strength of each predictor variable in the model, it is important to use the standardized coefficients (beta). The beta weight indicated that electricity supply is the strongest predictor $(\beta=0.480, \mathrm{P}=0.000)$. This value indicates that as electricity supply increases by one (1) standard deviation (6.470), SMEs stakeholder satisfactions increases by 0.480 standard deviation. The standard deviation of SMEs stakeholder satisfactions is (17.654) and so this constitutes a change of $(0.480 \mathrm{X} 17.654=8.473)$. Therefore, for every 6.470 rises on electricity supply, an extra 8.473 is associated to SMEs stakeholder satisfactions provided other predictors are held constant likewise, firm age (standardized $\beta=$ 0.226) this value indicates that as firm age increases by one standard deviation (1.597), SMEs stakeholder satisfactions also increases by 0.226 standard deviation, the standard deviation for SMEs stakeholder satisfactions is $(17.654)$ and so this constitute a change of 3.989 stakeholder satisfactions $(0.226 \mathrm{X} 17.654=3.989)$. Therefore, as firm age rises by 1.597 units, 3.989 extra stakeholder satisfactions can be expected. This interpretation is true only if the effects of electricity supply, firm size and leverage are held constant. In additions, firm size (standardized $\beta=$ 0.166) which implies that as the size increases by one (1) standard deviation (1.608), SMEs stakeholder satisfactions increases by 0.166 standard deviation. SMEs stakeholder satisfactions standard deviation is (17.654) and so this result in 2.930 growths $(0.166 \mathrm{X} 17.654=2.930)$, therefore, a firm with size rating 1.608 higher than another can expect 2.930 additional stakeholder satisfactions. This interpretation is true only if the effects of electricity supply firm age and leverage are held constant.

Finally, leverage (standardized $\beta=0.128$ ) signifies that as firm leverage increases by one (1) standard deviation (2.988), SMEs stakeholder satisfactions also increases by 0.128 standard deviation. The standard deviation for SMEs stakeholder satisfactions is (17.654) and so this constitutes a change of 2.259 stakeholder satisfactions (0.128 $\mathrm{X}$ 17.654). Therefore, for every 2.988 rises on leverage, an extra 2.259 is related to SMEs stakeholder satisfactions unless other predictors are held constant.

Table-5.Multiple regression coefficients of SMEs stakeholder satisfaction and predictor.

\begin{tabular}{|c|c|c|c|c|c|c|c|c|c|c|c|}
\hline & \multirow[b]{2}{*}{ Model } & \multicolumn{2}{|c|}{$\begin{array}{l}\text { Unstandardized } \\
\text { coefficients }\end{array}$} & \multirow{2}{*}{$\begin{array}{c}\text { Standardized } \\
\text { coefficients } \\
\text { Beta }\end{array}$} & \multirow[b]{2}{*}{$\mathbf{t}$} & \multirow[b]{2}{*}{ Sig. } & \multicolumn{3}{|c|}{ Correlations } & \multicolumn{2}{|c|}{$\begin{array}{c}\text { Collinearity } \\
\text { statistics }\end{array}$} \\
\hline & & B & $\begin{array}{l}\text { Std. } \\
\text { error }\end{array}$ & & & & $\begin{array}{l}\text { Zero- } \\
\text { order }\end{array}$ & Partial & Part & $\begin{array}{l}\text { Toler } \\
\text { ance }\end{array}$ & VIF \\
\hline \multirow[t]{5}{*}{1} & (Constant) & 19.698 & 5.229 & & 3.767 & .000 & & & & & \\
\hline & Elect access & 1.311 & .143 & .480 & 9.138 & .000 & .646 & .508 & .414 & .743 & 1.346 \\
\hline & Age & 2.501 & .568 & .226 & 4.404 & .000 & .493 & .273 & .200 & .778 & 1.286 \\
\hline & Size & 1.826 & .532 & .166 & 3.434 & .001 & .386 & .216 & .156 & .875 & 1.143 \\
\hline & Leverage & .754 & .268 & .128 & 2.813 & .005 & .166 & .179 & .127 & .996 & 1.004 \\
\hline
\end{tabular}

\subsubsection{Collinearity Statistics}

Table 5 further provided collinearity statistics. The model showed that multi-collinearity was not serious, since the tolerance values all well above 0.2 and VIF value are all well below 10; therefore this study safely conclude that there is no multi-collinearity within the data. Moreover, the Durbin-Watson value was 2.409, suggesting no evidence of auto-correlation of the errors. The value of cook's distance 0.099 less than 1.00 suggest that there is no potential problems with the outliers.

\subsubsection{Linearity Normality andHomoscedastiaty Statistics}

The graph of ZRESID and SPRED in Figure A (see appendix B) showed a random array of dots evenly dispersed around zero (0). This is an indicative of a situation in which the assumptions of linearity and homoscedasticity were accomplished, for test of normality of residuals, both histogram and normality probability plot in Figure A shows that histogram reflects a normal distribution (a bell-shaped curve) while normal probability plot reveals a straight line implies a normal distribution, and the points represents the observed residuals. Finally scatter plot, shows the strong positive relationship to SMEs stakeholder satisfactions. For electricity supply with cloud of dots evenly spaced out around the gradient line, indicating homoscedaslicity.

\subsection{Discussion of Findings}

The objective of this research was to explore the relationships between electricity supply and SMEs stakeholder satisfactions. Hypothesis was tested using multiple regression analysis to establish the relationships. The multiple regression analysis found statistically significant positive relationship between electricity access and SMEs stakeholder satisfactions while firm characteristics: firm size, age and leverage were held constant. Electricity access and firm age were the strongest predictors of SMEs stakeholder satisfactions. These results provide compelling evidence in support of the relationships between electricity access and stakeholder satisfactions. Generally the results suggest that those who aim to achieve higher satisfaction for business owners, employees and customer etc should consider access to electricity supply and firm age. These results are certainly in parallel with prior writings on the importance of electricity supply and SMEs performance such as Fadderke and Bogetic (2006); Grimm et al. (2012) and Kirubi et al. (2009).

The findings of the present study agree with Ukpong (1993) that irregular electricity supply has been a major bane to output growth and that erratic power supply has adverse impact on productivity growth of manufacturing sector in Nigeria. They recommended that the power sector by means of guided private sector initiative should be given more attention for the growth of the nation's economy to thrive. 
The statistically significant relationships between electricity supply and SMEs performance affirms the view of Solomon and Yao (2015) who indicate that power outage experience has a negative effect on SMEs growth and pushes the operation cost of businesses high due to the high cost of alternative energy supply and the damages of assets through the power fluctuations. The operational cost in effect also have a damming effect on the growth of the SMEs, since most of the revenue meant for reinvesting will rather goes to the servicing of electricity and alternative power bills.

\section{Conclusion and Recommendations}

Based on the hypothesis results and the research discussion, it can be concluded that there is a strong positive link between energy and SMEs stakeholder satisfactions while firm characteristics (firm size, firm age and leverage) are kept constant. This significant relationship leads to high prediction power of electricity access, firm characteristics and stakeholder satisfactions. Hence, this study recommend that entrepreneurs, energy policy makers and researchers should take cognizance of the significant of electricity access and firm characteristics (firm size, age, leverage) in the process of investigating and analyzing SMEs stakeholder satisfactions. This is because some variables (electricity access, firm age) are found to have a strong power in predicting stakeholder satisfactions while some variables (firm size and leverage) have weak power in predicting stakeholder satisfactions in Nigerian firms.

As access to electricity is found to be related to SMEs stakeholder satisfactions, increasing energy supply in Nigerian SMEs will have a positive influence on stakeholder satisfactions. Increasing electricity supply should involve optimal production and utilization of generation capacity and/or reduction of transmission and distribution losses. When this is achieved, the SMEs subsector will be in position to effectively lead in the drive towards industrializing the Nigerian economy.

The government should ensure that the SMEs subsector enjoys higher proportion of the power supply compared with the totality of the other sectors of the economy. SMEs villages/clusters should be built to promote industrial activities on the basis that access to reliable electricity supply is collectively and affordably provided by the relevant host authorities to investors and operators. In the absence of a better quality supply of electricity, improved quality and information about outages can help. Policy makers should help SMEs by providing reliable load shedding schedules. This would enable them to plan production around outages.

Above all, if off-grid electrification project is properly harnessed, is a likely solution to the perennial problem of power outages to small scale businesses subsector with the abundance of oil, gas resources and the renewable energies (solar and wind) in Nigeria. Therefore, efforts should be made by relevant authorities, tasked with the promotion of SMEs in Nigeria, to facilitate the provision and subsidized costs of procuring these renewable energy systems.

\section{References}

Akuru, U.B. and O.I. Okoro, 2011. Economic implications of constant power outages on SMEs in Nigeria. Available from https://www.researchgate.net/profile/OI_Okoro/publications.

Doe, F. and E.S. Asamoah, 2014. The effect of electric power fluctuations on the profitability and competitiveness of SMEs: A study of SMEs within the Accra business district of Ghana. Journal of Competitiveness, 6(3): 32-48.Available at: https://doi.org/10.7441/joc.2014.03.03.

Fadderke, J. and Z. Bogetic, 2006. Infrastructure and growth in South Africa: Direct and indirect productivity impacts of nineteen infrastructure measures. Washington D.C: World Bank Policy Reseach Working Paper.

Grimm, M., R. Hartwig and J. Lay, 2011. How much does utility access matter for the performance of micro and small enterprises? Available from http://wwww.wds.worldbank.org/external/default.

Grimm, M., R. Hartwig and J. Lay, 2012. How much does utility access matter for the performance of micro and small enterprises? Available from http://wwww.wds.worldbank.org/external/default.

Hoskisson, R.E., M.A. Hitt and R.D. Ireland, 2008. Computing for advantage. 2nd Edn., Cincinnati: Thomson South-Western.

Jackson, M., 2003. Systems thinking: Creative holism for managers. Chichester: John Wiley \& Sons, Ltd.

Kirubi, C., A. Jacobson, D.M. Kammen and A. Mills, 2009. Community-based electric micro-grids can contribute to rural development: Evidence from Kenya. World Development, 37(7): 1208-1221.Available at: https://doi.org/10.1016/j.worlddev.2008.1 1.005.

Krejcie, R.V. and D.W. Morgan, 1970. Determining sample size for research activities. Educational and Psychological Measurement, 30(3): 607-610.Available at: https://doi.org/10.1177/001316447003000308.

Krizanic, F., 2007. The European market of electricity and natural gas. Ljuljana: EIB Forum.

McAdam, R., 2000. Quality models in an SME context: A critical perspective using a grounded approach. International Journal of Quality \& Reliability Management, 17(3): 305-323.Available at: http://dx.doi.org/10.1108/02656710010306166.

Okafor, E.E., 2014. Reforms in the power sector and implications for industrial development in Nigeria: The case of difference between six half a dozen? Ibadan Journal of the Social Science, 12(1): 1-18.

Solomon, K.F. and L. Yao, 2015. Electricity power insecurity and SMEs growth: A case study of the cold store operators in the asafo market area of the Kumasi Metro in Ghana. Open Journal of Business and Management, 3(3): 312-325.

Ukpong, I., 1993. An analysis of the causes of power shortage in Nigeria. The Nigerian Journal of Economic and Social Studies, 18(1): 34-39.

Wang, J.E., 2002. Outage costs and strategy analysis for hi-tech industries: A fuzzy multiple goal approach. International Journal of Quality \& Reliability Management, 19(8/9): 1068-1087.Available at: https://doi.org/10.1 108/02656710210438131.

\section{Appendix A}

\section{Part A: Electricity Supply Survey Questionnaire.}

Instruction: Please respond as candidly as possible to the following statements by rating $(\sqrt{ })$ a number between 1 and 5 that best represents your organization in term of availability per hour of electricity supply as it was during the past three years. Use the scale provided below to indicate the option that most accurately reflects your assessment on each statement. Choose only ONE option for each statement. 


\begin{tabular}{c|c|c|c|c}
\hline Very low & Low & Average & High & Very high \\
\hline 1 & 2 & 3 & 4 & 5 \\
\hline
\end{tabular}

\begin{tabular}{|c|c|c|c|c|c|c|}
\hline \multicolumn{7}{|c|}{ Electricity supply } \\
\hline ESO1 & Number of uninterrupted power supply in a typical month & 1 & 2 & 3 & 4 & 5 \\
\hline ESO2 & Duration of a typical reliable electricity supply & 1 & 2 & 3 & 4 & 5 \\
\hline ESO3 & $\begin{array}{l}\text { If there were uninterrupted power supply, average duration of a } \\
\text { typical reliable power supply }\end{array}$ & 1 & 2 & 3 & 4 & 5 \\
\hline ESO4 & Maximum percentage voltage fluctuation during a month. & 1 & 2 & 3 & 4 & 5 \\
\hline ESO5 & Number of enterprises rely only on grid electricity & 1 & 2 & 3 & 4 & 5 \\
\hline ESO6 & Duration of firm operation relying on grid electricity & 1 & 2 & 3 & 4 & 5 \\
\hline ESO7 & $\begin{array}{l}\text { Gains due to reliable electricity access in terms of percentage annual } \\
\text { sales }\end{array}$ & 1 & 2 & 3 & 4 & 5 \\
\hline ESO8 & Monthly quality of reliable electricity consumed & 1 & 2 & 3 & 4 & 5 \\
\hline ESO9 & Average outage time during a month. & 1 & 2 & 3 & 4 & 5 \\
\hline $\mathrm{ES} 10$ & $\begin{array}{l}\text { If grid electricity is used, average proportion of electricity supply } \\
\text { from grid }\end{array}$ & 1 & 2 & 3 & 4 & 5 \\
\hline
\end{tabular}

Part B:SMEs Performance Survey Questionnaire.

Instruction: Please respond as candidly as possible to the following statements by rating $(\sqrt{ })$ a number between 1 and 5 that best represent your organization non-financial performance (stakeholders satisfaction) as it was during the past three years. Use the scale provided below to indicate the option that most accurately reflects your assessment on each statement. Choose only $\mathbf{O N E}$ option for each statement.

\begin{tabular}{c|c|c|c|c}
\hline Very low & Low & Average & High & Very high \\
\hline 1 & 2 & 3 & 4 & 5 \\
\hline
\end{tabular}

\begin{tabular}{|c|c|c|c|c|c|c|}
\hline \multicolumn{7}{|c|}{ Employees satisfaction } \\
\hline ESO1 & Investments in employees development and training & 1 & 2 & 3 & 4 & 5 \\
\hline ESO2 & Extent of employees turnover & 1 & 2 & 3 & 4 & 5 \\
\hline ESO3 & Number or percentage of employees promoted during a year & 1 & 2 & 3 & 4 & 5 \\
\hline ESO4 & $\begin{array}{l}\text { Percentage of employees who rated their careers development } \\
\text { opportunities as above or excellent in the annual employee survey }\end{array}$ & 1 & 2 & 3 & 4 & 5 \\
\hline ESO5 & Extent of competitiveness of compensation package & 1 & 2 & 3 & 4 & 5 \\
\hline ESo6 & Safe work conditions & 1 & 2 & 3 & 4 & 5 \\
\hline ESO7 & Pleasant work environment & 1 & 2 & 3 & 4 & 5 \\
\hline ESO8 & Fairness of your firm wage and reward policies & 1 & 2 & 3 & 4 & 5 \\
\hline ESO9 & $\begin{array}{l}\text { Extent of inclusion on list of best companies your employees wish to } \\
\text { work for. }\end{array}$ & 1 & 2 & 3 & 4 & 5 \\
\hline ES10 & Extent of employees' inclusion in decision matter to them. & 1 & 2 & 3 & 4 & 5 \\
\hline \multicolumn{7}{|c|}{ Customers satisfaction } \\
\hline CSO1 & Number of complaints per customers per year & 1 & 2 & 3 & 4 & 5 \\
\hline $\mathrm{CSO} 2$ & $\begin{array}{l}\text { Percentage of time customers ranking products/services very good or } \\
\text { excellent on survey }\end{array}$ & 1 & 2 & 3 & 4 & 5 \\
\hline CSO3 & Average number of time customers report on products/services quality. & 1 & 2 & 3 & 4 & 5 \\
\hline CSO4 & Perceived customers fair treatment during transaction & 1 & 2 & 3 & 4 & 5 \\
\hline CSO5 & Extent of your organization product safety concern & 1 & 2 & 3 & 4 & 5 \\
\hline CSO6 & $\begin{array}{l}\text { Percentage of time customers ranking your company innovation very } \\
\text { good or excellent on survey }\end{array}$ & 1 & 2 & 3 & 4 & 5 \\
\hline CSO7 & Repurchase rate & 1 & 2 & 3 & 4 & 5 \\
\hline CSO8 & Number of new products/services launched during a year. & 1 & 2 & 3 & 4 & 5 \\
\hline CSO9 & Number of goods returned per year. & 1 & 2 & 3 & 4 & 5 \\
\hline CS10 & General customers satisfaction & 1 & 2 & 3 & 4 & 5 \\
\hline \multicolumn{7}{|c|}{ Owners satisfaction } \\
\hline OSO1 & Extent of return on investment & 1 & 2 & 3 & 4 & 5 \\
\hline OSo2 & Extent of liquidity soundness & 1 & 2 & 3 & 4 & 5 \\
\hline OSO3 & Perceived riskiness of investment & 1 & 2 & 3 & 4 & 5 \\
\hline OSO4 & Average number of stockholders proposals per year & 1 & 2 & 3 & 4 & 5 \\
\hline OSO5 & Extent of compensation levels of top managers & 1 & 2 & 3 & 4 & 5 \\
\hline OSo6 & Extent of stability of investment & 1 & 2 & 3 & 4 & 5 \\
\hline OSO7 & Extent of price-to-earnings ratio & 1 & 2 & 3 & 4 & 5 \\
\hline OSo8 & Rate of market-share growth & 1 & 2 & 3 & 4 & 5 \\
\hline OSO9 & Extent of ownership concern and attention & 1 & 2 & 3 & 4 & 5 \\
\hline OS10 & General stockholders satisfaction. & 1 & 2 & 3 & 4 & 5 \\
\hline
\end{tabular}

PART C: SMEs Characteristics Survey Questionnaire.

Instruction: Please respond as candidly as possible to the following statements by rating $(\sqrt{ })$ a number between 1 and 5 that best represents your organization in term of size and leverage as it was during the past three years. Use the scale provided below to indicate the option that most accurately reflects your assessment on each statement. Choose only ONE option for each statement. 


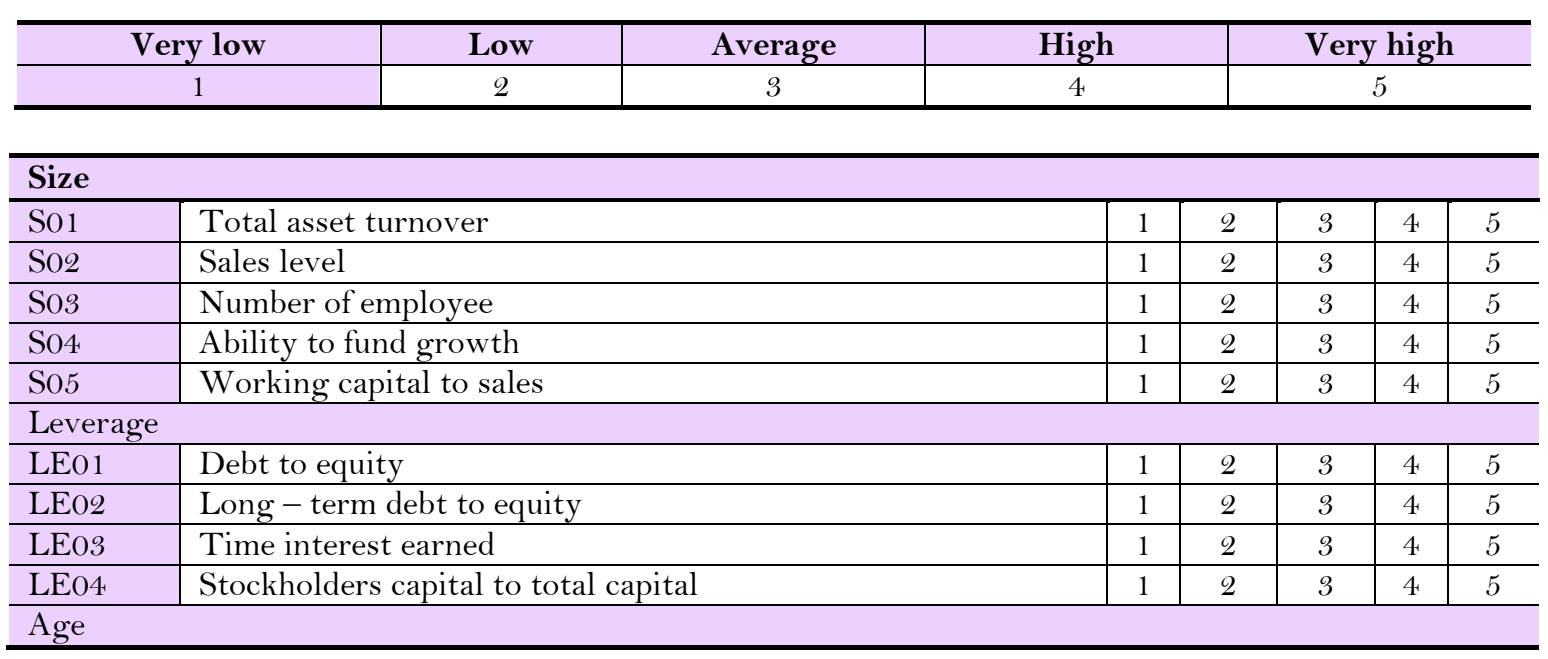

A01: How long has your firm been in operation?

\begin{tabular}{l|l}
\hline Less than $\mathbf{5}$ years & $\mathbf{1}$ \\
\hline $5-10$ years & 2 \\
\hline $11-15$ years & 3 \\
\hline $16-29$ years & 4 \\
\hline Above 20 years & 5 \\
\hline
\end{tabular}

A02: When was your enterprise incorporated?

\begin{tabular}{l|l}
\hline Less than $\mathbf{5}$ years ago & $\mathbf{1}$ \\
\hline $5-10$ years ago & 2 \\
\hline $11-15$ years ago & 3 \\
\hline $16-29$ years ago & 4 \\
\hline More than 20 years ago & 5 \\
\hline
\end{tabular}

A03: How many years of business experience does your enterprise has?

\begin{tabular}{l|c}
\hline Less than $\mathbf{5}$ years & $\mathbf{1}$ \\
\hline $5-10$ years & 2 \\
\hline $11-15$ years & 3 \\
\hline $16-29$ years & 4 \\
\hline Above 20 years & 5 \\
\hline
\end{tabular}

A04: How long was your enterprise in existence?

\begin{tabular}{l|l}
\hline Less than 5 years & 1 \\
\hline $5-10$ years & 2 \\
\hline $11-15$ years & 3 \\
\hline $16-29$ years & 4 \\
\hline Above 20 years & 5 \\
\hline
\end{tabular}

\begin{tabular}{l|c} 
A05: How long was your enterprise in business trading? \\
\hline Less than 5 years & 1 \\
\hline $5-10$ years & 2 \\
\hline s1 1 - 15 years & 3 \\
\hline $16-29$ years & 4 \\
\hline Above 20 years & 5 \\
\hline
\end{tabular}

\section{Appendix B}

Histogram

Dependent Variable: S.Satisfac

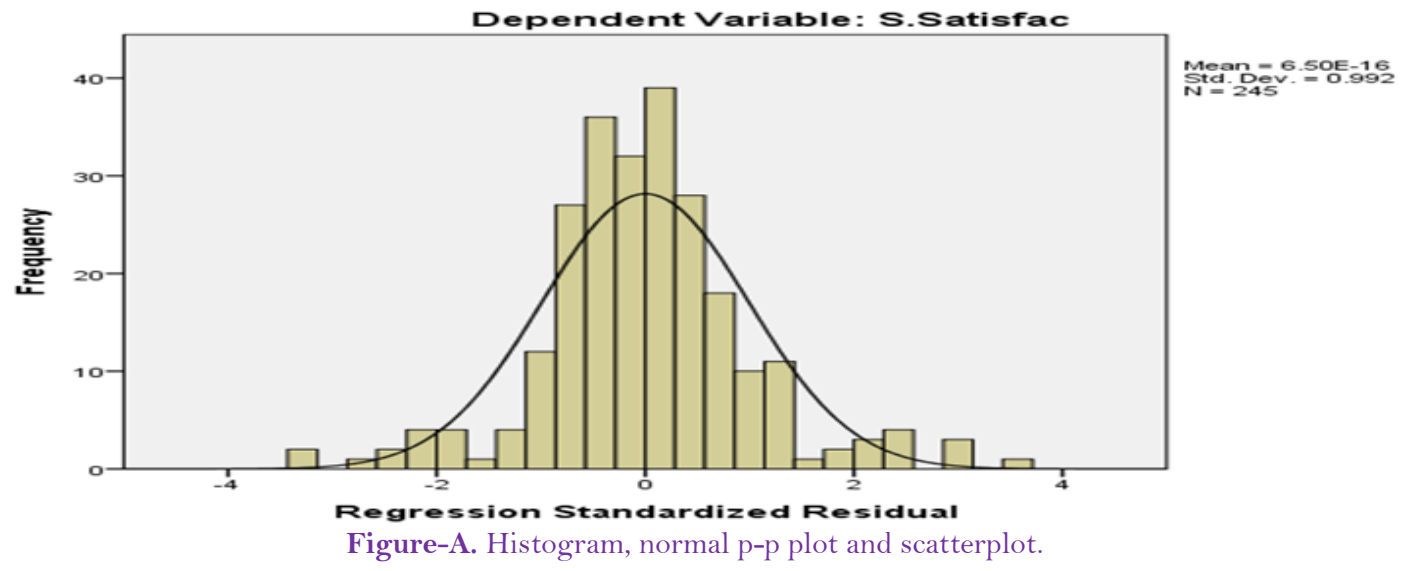




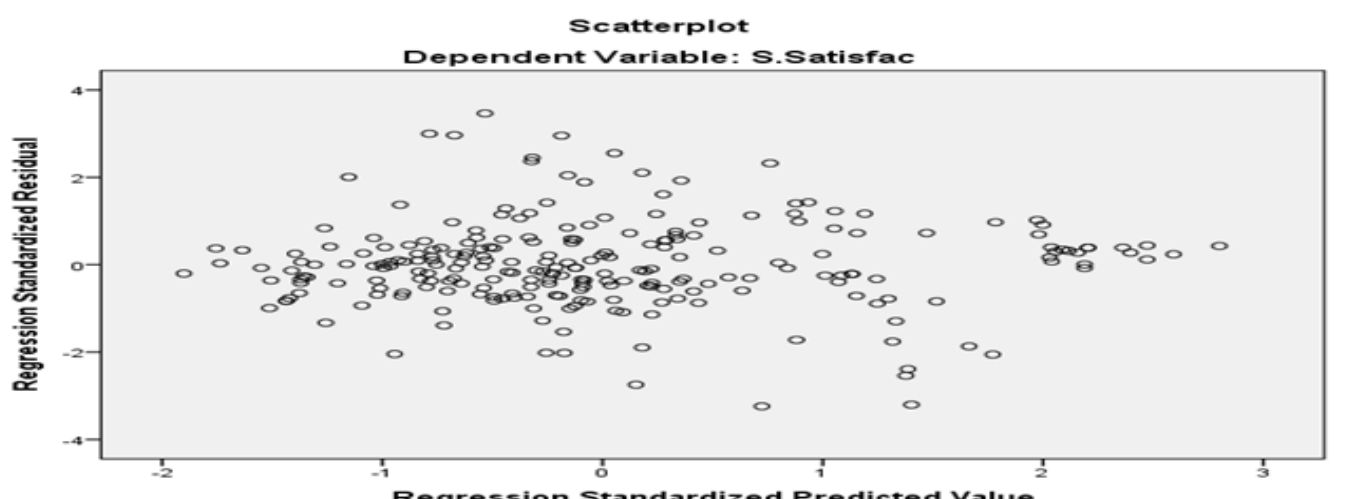

Figure-B. Scatterplot.

\section{Normal P-P Plot of Regression Standardized Residual}

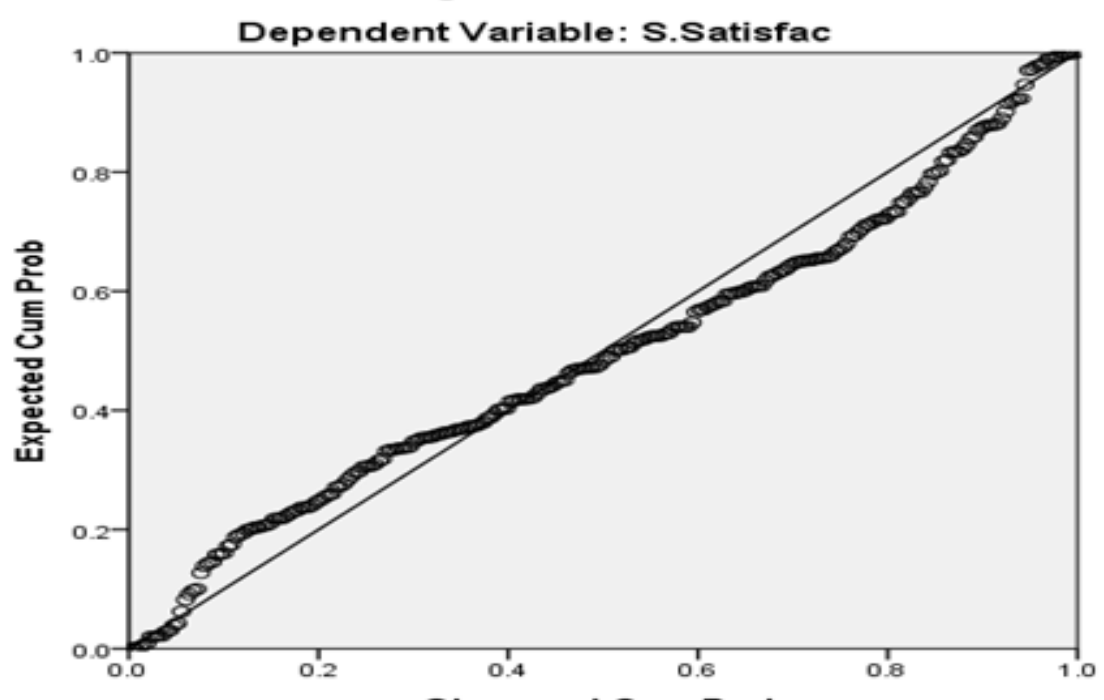

Observed Cum Prob

Figure-C. Normal P-P plot.

Citation | Abubakar Sabo; Olusegun Kazeem Lekan (2019). Does Electricity Access Relate to Stakeholders' Satisfaction? Empirical Evidence from Small and Medium Enterprises in North-West,

Nigeria. Asian Business Research Journal, 4: 35-43.

History:

Received: 17 September 2019

Revised: 21 October 2019

Accepted: 26 November 2019

Published: 30 December 2019

Licensed: This work is licensed under a Creative Commons

Attribution 3.0 License $(\mathrm{cc}) \mathbf{E}$

Publisher: Eastern Centre of Science and Education
Acknowledgement: Both authors contributed to the conception and design of the study.

Funding: This study received no specific financial support.

Competing Interests: The authors declare that they have no conflict of interests.

Transparency: The authors confirm that the manuscript is an honest, accurate, and transparent account of the study was reported; that no vital features of the study have been omitted; and that any discrepancies from the study as planned have been explained.

Ethical: This study follows all ethical practices during writing.

Eastern Centre of Science and Education is not responsible or answerable for any loss, damage or liability, etc. caused in relation to/arising out of the use of the content. Any queries should be directed to the corresponding author of the article. 